\title{
Observations on phonetic and metrical patterns in Spanish-language proverbs
}

\author{
Jordi Martínez Martínez, Gemma Bel Enguix and Liliana Torres Floress \\ Universidad Nacional Autónoma de México, Instituto de Ingeniería, \\ Grupo de Ingeniería Lingüística, Mexico City, Mexico \\ jor.mtzmtz@gmail.com \\ gbele@iingen. unam.mx \\ lilianatorres0412@gmail.com
}

\begin{abstract}
This paper aims at starting a new research line on Spanish proverbs with the help of computational tools. The first step to reach this goal was the compilation of a corpus of proverbs from existing digital sources. Later, a phonetic study of the items of the corpus was carried out, approaching the syllabic structure and metrical features, as well as regularities and patterns in the configuration of paremiological units. For the future, we expect to complete this work by extending the research to syntactic and semantic features and build a system capable of searching for analogue structures in large collections of texts.
\end{abstract}

Keywords: paremiology, poetic meter, rhyme, Spanish proverbs

\section{Introduction}

\subsection{Phonetic and metrical patterns in proverbs}

Exploring the relationship between metrical or phonetic features and proverbs is, by no means, a new approach in paremiological studies: reflections on the nature of such kind of patterns are common in literature, more often than not, as casual remarks which may still await for a more rigorous approach [1].

Nevertheless, phonetic regularities found in proverbs have been hypothesized to serve as an instrument of internal organization [16], as a sign of an utterance's proverbiality $[1,2]$ or as a mnemotechnical device [6].

Empirically oriented approaches to the study of phonetic regularities in proverbs seem to be scarce, and, as such, their possible applications in paremiography and paremiology have not been explored, i.e. as criteria for search queries in databases or as a variables in automatic or manual identification tasks.

In Spanish-language proverbs, such patterns have been observed to occur as rhyme (specially as phrase-final assonance), isosyllabism, binary (prosodic, syntactic) structure, and a certain intonational pattern. Several works approach the topic, among others $[1,2,3,4,7,9,12,13,15]$. 


\subsection{Objectives}

In this paper we aim to go deeper into a corpus-based computational approach to Spanish paremiology, that has not been enough developed so far.

Moreover, we have the goal to corroborate some remarks on the phonetic regularities found in Spanish proverbs. The following hypotheses were considered:

1. Binary proverbs were expected to predominate over non-binary proverbs.

2. Rhymed proverbs were expected to predominate over rhymeless proverbs.

3. In binary and rhymed proverbs, assonance was expected to be the dominant type of rhyme, over consonance.

4. Proverbs formed by two or more units were expected to exhibit isosyllabicity.

5. Octosyllabic proverb hemistichs were expected to predominate over nonoctosyllabic hemistichs.

To do so, we describe a basic methodology which consisted on the creation of a corpus of proverbs with metrical and phonetic labeling.

\section{Methodology}

\subsection{The corpus}

Three on-line databases were used as basis for our corpus: Refranero mexicano [11], and the Spanish sub-corpora of both Refranero multilingüe [14], and ParemioRom $[8]^{1}$.

The selection of these repertoires was based on the following criteria: (a) documentation of their materials, (b) their digital nature, which facilitated the processing of the proverbs extracted from each of them, and (c) the diatopic variety associated with the sources from which the proverbs were extracted.

The initial corpus consisted of a total of 4734 proverbs. To filter repeated or similar ones, the FuzzyWuzzy library [5] was used, called from the Python programming language (Version 3.6.1).

FuzzyWuzzy uses Levenshtein's distance to compare strings of characters [5]. The similarity parameter for matched strings was set at $85 \%$. This allowed us to identify groups of proverbs that exhibited similarity equal or greater to the set parameter.

Out of any group of matched proverbs, we decided to keep those belonging to Refranero mexicano; while in those instances where the matched strings were made up of proverbs from the Peninsular Spanish sources, we decided to keep the proverbs that belonged to ParemioRom.

In the instance of a group of matched strings that belonged to a single source, it was decided to retain the first selected member of such group.

After applying this filter to the initial corpus, the repertoire was reduced to 4620 proverbs. The composition of the corpus is set out in Table 1.

\footnotetext{
${ }^{1}$ Some proverbs were not taken into account: dialogue proverbs, incomplete or censored proverbs and some blank-slot proverbs which contained its variants in the same string (i.e., El que siembra, o siembre, o sembró, su maiz, que se coma su pinole).
} 
Table 1. Composition of the corpus.

\begin{tabular}{llll}
\hline Source & \multicolumn{3}{c}{ Region Proverbs $\%$} \\
\hline Refranero mexicano & Mexico & 1975 & 42.75 \\
Refranero multilingüe & Spain & 1622 & 35.11 \\
ParemioRom & Spain & 1023 & 22.14 \\
\hline Totals & - & 4620 & 100.00 \\
\hline
\end{tabular}

\subsection{Corpus processing}

The separation of proverbs into smaller units was carried out in two phases. Firstly, the punctuation marks already present in the proverbs were taken advantage of: commas (,) and semicolons (;) were combined with adjacent vertical bars $(\mid)$ automatically. The second part consisted in a manual revision of the output, with the aim of dismissing irrelevant divisions (i.e. some vocatives) and dividing the proverbs that did not signal internal divisions through punctuation, but with other types of boundaries, such as rhyme, conjunctions or, to a lesser extent, other signs not initially considered, such as colons (:).

We agreed to denominate such internal prosodic constituents as hemistichs, following Pérez Martínez [10], in an analogy of its use in metrical studies.

The divided proverbs were processed with a series of simple rule-based scripts called from the Python programming language. These take as input a divided proverb, on whose hemistichs apply a set of syllabification rules, a stressed syllable identifier ${ }^{2}$, and a resyllabification cycle of whose output is inferred a binary string (interpreted as series of stressed (1) and unstressed (0) syllables), equivalent to the metrical structure of the hemistichs, as illustrated by the examples in Table 2 .

Table 2. Examples of inputs and outputs of the rule-based scripts. Vertical bars (|) denote hemistich boundaries; stressed and unstressed syllables are represented by 1 and 0 , respectively.

\begin{tabular}{lc}
\hline Divided proverb & Metrical structure \\
\hline A cada pajarillo|le gusta su nidillo & $0100010 \mid 0100010$ \\
Pobre y tecolotero, $\mid$ no te irás con dinero & $1000010 \mid 0010010$ \\
\hline
\end{tabular}

From this process, the following variables were obtained for each hemistich: number of graphical syllables, number of beats, position of the last stressed syllable and metrical structure.

\footnotetext{
${ }^{2}$ It should be noted that the scripts employed in this investigation automatically consider any monosyllabic word as unstressed.
} 
The identification of metrical syllables entailed the distinction of at least four different variables: phonological syllables, graphical syllables, beats, and metrical syllables.

Phonological syllables were assumed to be equivalent to the underlying syllabical representation of the utterance (the proverb), which was not taken into account in this study; graphical syllables were obtained through the output of the syllabification cycle of the scripts used and correspond to the syllabic divisions of isolated word tokens; beats were obtained through the output of the rules of resyllabification cycle and correspond to the units of a string of strong (stressed) and weak (unstressed) syllables. Finally, metrical syllables correspond to the output of the metrical analysis of the previous output, according to Spanish poetic meter conventions.

The number of metrical syllables (MS) per hemistich was determined on the basis of the number of beats per hemistich plus the application of a subtraction or addition operation given the following situations: $\mathrm{MS}=$ beats -1 , if the last stressed beat is the third-to-last pulse of the string; MS = beats, if the last stressed beat is the penultimate beat of the string; $\mathrm{MS}=$ beats +1 , if the last stressed beat is the last beat of the string.

Rhyme labeling was done manually. Two types of rhyme were distinguished: assonance and consonance. Only hemistich-final rhymes were taken into account. Consonance was defined as the perfect match of the phonic material contained between the nucleus of the last stressed syllable and the right edge of two or more hemistichs. Assonance, on the other hand, was taken as the partial coincidence of phonic material contained between the nucleus of the las stressed syllable and the right edge of two or more hemistichs, restricted only to syllabic nuclei.

Consonant rhymes were required to match perfectly the syllabic nuclei involved, including vowels $/ \mathrm{i}, \mathrm{u} /$ associated to the left edge of syllabic nuclei in ascending diphthongs.

Only one dialectal feature was taken into account in the labeling of rhymes, that of the distinction between phonemes $/ \mathrm{s} /$ and $/ \theta /$ in most European varieties of Spanish. Therefore, some rhyme schemes were labeled as assonant or consonant depending on the geographical region associated with the source material (Mexico, in the case of Refranero mexicano, or Spain, in the case of Refranero multilingüe and ParemioRom).

The finest labeling was concentrated only on proverbs of two hemistichs, the most numerous, where the two rhyme types are distinguished. Proverbs of three or more hemistichs that presented a type of rhyme on the edge of their hemistichs were only labeled as rhymed. Proverbs formed by a single hemistich were considered to be rhymeless.

\section{Results}

\subsection{Hemistichs}

Number of hemistichs. As shown in Table 3, binary proverbs, formed by two hemistichs, made up almost three quarter parts (74.94\%) of the corpus, followed 
by single hemistich proverbs, proverbs formed by three hemistichs and proverbs formed by four hemistichs. Proverbs formed by five or more hemistichs made up only $0.86 \%$ of the corpus. A total of 9561 hemistichs were counted.

Table 3. Proverbs by number of hemistichs.

\begin{tabular}{cll}
\hline \multicolumn{3}{c}{ Hemistichs Proverbs $\%$} \\
\hline 1 & 572 & 12.38 \\
2 & 3463 & 74.94 \\
3 & 345 & 7.47 \\
4 & 200 & 4.33 \\
5 & 22 & 0.48 \\
6 & 14 & 0.30 \\
8 & 3 & 0.06 \\
10 & 1 & 0.02 \\
\hline Total & 4620 & 100.00 \\
\hline
\end{tabular}

Hemistich length. As shown in Table 4, octosyllabic hemistichs were the most numerous, making up $22.62 \%$ of the corpus, but, unlike the distribution of proverbs by number of hemistichs, greater variety was found, especially among the ones with a length of eight metrical syllables or less ( $82.84 \%$ of the corpus).

Table 4. Hemistichs by number of metrical syllables.

\begin{tabular}{lll}
\hline MS & \multicolumn{2}{l}{ Hemistichs $\%$} \\
\hline$<4$ & 539 & 5.64 \\
4 & 996 & 10.42 \\
5 & 1555 & 16.26 \\
6 & 1429 & 14.95 \\
7 & 1238 & 12.95 \\
8 & 2163 & 22.62 \\
9 & 627 & 6.56 \\
$>9$ & 1014 & 10.61 \\
\hline \multicolumn{2}{l}{ Total 9561} & 100.00 \\
\hline
\end{tabular}

\subsection{Rhyme}

Presence of hemistich-final rhyme. Rhymed proverbs made up a slight majority $(55.37 \%)$ of the corpus over rhymeless proverbs $(44.63 \%)$, as seen in Table 5 .

Rhymed proverbs by number of hemistichs. Distribution-wise, there seems to be a great correlation between binary structure and presence of rhyme, as up to $79.44 \%$ of rhymed proverbs were formed by two hemistichs (Table 6). 
Table 5. Proverbs by presence of rhyme.

\begin{tabular}{lcc}
\hline Rhyme & \multicolumn{2}{c}{ Proverbs $\%$} \\
\hline Rhymed & 2558 & 55.37 \\
Rhymeless & 2062 & 44.63 \\
\hline Total & 4620 & 100.00 \\
\hline
\end{tabular}

Table 6. Rhymed proverbs by number of hemistichs.

\begin{tabular}{lll}
\hline \multicolumn{3}{l}{ Hemistichs Rhymed proverbs $\%$} \\
\hline 2 & 2032 & 79.44 \\
3 & 298 & 11.65 \\
4 & 190 & 7.43 \\
5 & 20 & 0.78 \\
6 & 14 & 0.55 \\
8 & 3 & 0.12 \\
10 & 1 & 0.04 \\
\hline Total & 2558 & 100.00 \\
\hline
\end{tabular}

Type of rhyme. The most common type of rhyme found in rhymed proverbs formed by two hemistichs was consonance $(53.40 \%)$, with a slight difference over assonance $(46.6 \%)$, as shown in Table 7 .

Table 7. Types of rhyme in binary proverbs.

\begin{tabular}{lll}
\hline Rhyme & \multicolumn{2}{c}{ Proverbs \% } \\
\hline Assonance & 947 & 46.60 \\
Consonance & 1085 & 53.40 \\
\hline Total & 2032 & 100.00 \\
\hline
\end{tabular}

\subsection{Isosyllabicity}

Isosyllabicity was exhibited by only 1052 proverbs (22.77\%) out of a total 4620 . Then again, a strong affinity between this feature and binary structure was found, as $1012(96.2 \%)$ out of 1052 isosyllabic proverbs were formed by two hemistichs.

Metrical length seems to play an important role as well, as $47.05 \%$ of isosyllabic proverbs contained octosyllabic hemistichs (Table 8).

\subsection{Summary}

Regarding or hypotheses, binary proverbs did indeed predominate over non binary proverbs, forming up to $74.94 \%$ of the corpus. Octosyllabic hemistichs 
Table 8. Isosyllabic proverbs found in the corpus.

\begin{tabular}{crrrrrrr}
\hline & \multicolumn{7}{c}{ Hemistichs } \\
\cline { 2 - 6 } MS & Two Three Four Five Six Totals & $\%$ \\
\hline 2 & 3 & 0 & 0 & 0 & 0 & 3 & 0.29 \\
3 & 12 & 0 & 2 & 0 & 0 & 14 & 1.33 \\
4 & 95 & 3 & 1 & 0 & 0 & 99 & 0.93 \\
5 & 154 & 3 & 7 & 0 & 0 & 164 & 9.41 \\
6 & 129 & 3 & 4 & 0 & 1 & 137 & 15.59 \\
7 & 77 & 3 & 0 & 0 & 0 & 80 & 7.6 \\
8 & 482 & 8 & 5 & 0 & 0 & 495 & 47.05 \\
9 & 32 & 0 & 0 & 0 & 0 & 32 & 3.04 \\
10 & 13 & 0 & 0 & 0 & 0 & 13 & 1.24 \\
11 & 9 & 0 & 0 & 0 & 0 & 9 & 0.86 \\
12 & 4 & 0 & 0 & 0 & 0 & 4 & 0.38 \\
13 & 0 & 0 & 0 & 0 & 0 & 0 & 0 \\
14 & 0 & 0 & 0 & 0 & 0 & 0 & 0 \\
15 & 1 & 0 & 0 & 0 & 0 & 1 & 0.1 \\
16 & 1 & 0 & 0 & 0 & 0 & 1 & 0.1 \\
\hline Totals & 1012 & 20 & 19 & 0 & 1 & 1052 & 100.00 \\
\hline
\end{tabular}

$(22.62 \%)$ were the most common metrical type in our corpus, although there seems to exist a variety of metrical types, especially in hemistichs of eight or less metrical syllables. Rhymed proverbs were found to be more common than rhymeless proverbs, but only by a slight margin. Consonance, in turn, prevailed over asonance, but in similar conditions. Isosyllabicity exhibited a rather restricted presence in our corpus: only $22.77 \%$ of the proverbs were isosyllabic, and such feature seems to be strongly correlated to binary structure $(96.2 \%$ of isosyllabic proverbs) and octosyllabic hemistichs (47.05\% of isosyllabic hemistichs).

\section{Conclusions and future work}

This work has been focused on a preliminary quantitative analysis of internal structure, isosyllabicity and rhyme in a corpus of Spanish proverbs. The results seem to confirm this genre has strong metrical and prosodic features. However, some results, like the preference for consonant rhyme and the low presence of isosyllabicity, are surprising considering the mainstream opinions so far.

The future work has to include the identification of contexts where the proverbs appear and the identification in corpora of prosodic structures with the same patterns than the ones analyzed in here. The main objective for this work is the automatic retrieval of proverbs in large collection of texts.

Acknowledgements We thank Octavio Augusto Sánchez, author of the Python scripts used in this investigation, for the permission granted for using his original work, and the mexican Red Temática en Tecnologías del Lenguaje for the support to our project. 


\section{References}

1. Anscombre, J.C.: Estructura métrica y función semántica de los refranes. Paremia 8, 25-36 (1999)

2. Arora, S.: The perception of proverbiality. In: Mieder, W. (ed.) Wise Words: Essays on the Proverb, pp. 3-29. Routledge, Abingdon-on-Thames (1984/2015)

3. Baehr, R.: Manual de versificación española. Gredos, Madrid (1973)

4. Casares, J.: La frase proverbial y el refrán. Revista Universidad Pontificia Bolivariana 27(95), 36-49 (1964)

5. Cohen, A.: FuzzyWuzzy. Fuzzy String Matching in Python (2017), https://github.com/seatgeek/fuzzywuzzy

6. Corpas Pastor, G.: Manual de fraseología española. Gredos, Madrid (1996)

7. Crida Álvarez, C.A., Sevilla Muñoz, J.: La problemática terminológica en los estudios paremiológicos. Anuari de filologia. Estudis de lingüística 5, 67-77 (2015)

8. Gargallo Gil, J.E., Álvarez Pérez, X.A.: El Proyecto Paremiorom. Refranes meteorológicos y geoparemiología romance. Estudis Romànics 36, 313-324 (2014)

9. Navarro Tomás, T.: Manual de entonación española. Guadarrama, Madrid, 4 edn. (1974)

10. Pérez Martínez, H.: Refranero mexicano. Lengua y Estudios Literarios, Academia Mexicana de la Lengua, Fondo de Cultura Económica, México (2004)

11. Pérez Martínez, H.: Refranero mexicano http://www.academia.org.mx/universo:lema/obra:Refranero-mexicano

12. Quilis, A.: Métrica española. Ariel Letras, Ariel, Madrid, 15 edn. (2013)

13. Sevilla Muñoz, J., Crida Álvarez, C.: Las paremias y su clasificación. Paremia 22, 105-114 (2013)

14. Sevilla Muñoz, J., Zurdo Ruiz-Ayúcar, M.I.T.: Refranero multilingüe (2009), http://cvc.cervantes.es/lengua/refranero/

15. Taylor, A.: The Proverb. Harvard University Press, Cambridge, MA (1931)

16. Toporov, V.N.: Folk Poetry: General Problems. In: Sebeok, T. (ed.) Current Trends in Linguistics, vol. 12. Linguistics and Adjacent Arts and Sciences, pp. 684-739. Mouton, The Hague (1974) 